\title{
ФОРМУВАННЯ ПРОФЕСІЙНОЇ КОМПЕТЕНТНОСТІ МАЙБУТНІХ МЕДИЧНИХ СЕСТЕР В ОСВІТНЬОМУ ПРОЦЕСІ ФАХОВОЇ ПІДГОТОВКИ МЕДИЧНОГО КОЛЕДЖУ
}

Анотація. Розглянуто теоретичні засади фрормування майбутніх медичних сестер в освітньому процесі фрахової підготовки медичного коледжу відповідно до сучасних вимог Концепщії розвитку охорони здоров’я населення України. Проведено аналіз психолого-педагогічних джерел, нормативних документів із організації освітнього та виховного процесів медичних освітніх закладів. З'ясовано особливості фрормування професійної компетентності майбутніх медичних сестер котрі пов'язані з розвитком пізнавальної активності, особистісних якостей, творчого потенціалу, загальної культури, професійної майстерності. Охарактеризовано структуру професійної підготовки майбутніх медичних сестер яка характеризуеться управлінням освітнім процесом і шляхами підвищення ефективності процесу підготовки майбутніх медичних сестер до фрахової діяльності. Виявлено пріоритети спрямованості педагогічного процесу на профресійної компетентності майбутніх медичних сестер в освітньому процесі медичного коледжу.

Ключові слова: освітній процес, педагогічний процес, майбутні медичні сестри, фрахова діяльність, профресійна компетентність.

Chornobryva Natalia, Chornobryva Liudmyla Separated Subdivision "Rokytne Professional Medical College" of Municipal Institution of Higher Education "Rivne Medical Academy" of Rivne Regional Council

\section{FORMATION OF PROFESSIONAL COMPETENCE OF FUTURE NURSES IN THE EDUCATIONAL PROCESS OF PROFESSIONAL TRAINING OF MEDICAL COLLEGE}

Summary. The theoretical bases of orientation of pedagogical process on formation of professional competence of future nurses on professional activity according to modern requirements of the Concept of development of public health services of the population of Ukraine are considered. Features of formation of professional competence of future nurses in the educational process of professional training of medical college which are connected with development of cognitive activity, personal qualities, creative potential, general culture, professional skill on the basis of the competence approach, namely: social need in professional activity of future nurses. ; high qualities of a citizen of Ukraine and motivational values; awareness of future nurses of the need for professional readiness to work in the primary care system and the introduction of insurance medicine; deep motivation of future nurses to the educational process on the basis of the competence approach; availability of appropriate qualities for the formation of knowledge, skills and abilities to synthesize and analyze information, make professional decisions in accordance with modern standards of medical care, taking into account the current level of development of medical science and practice. The structure of professional training of future nurses, which is characterized by the management of the educational process and ways to increase the efficiency of the process of training future nurses for professional activities, which is considered to be established: characterizes the social order; pedagogical system; informational, technical, educational and methodological, providing the educational process of medical schools); information and educational environment of the medical college; management of the educational process in the areas of improving the efficiency of the process of training future nurses: methods, tools, forms, types of work (methodical, educational, teaching, scientific); the focus of the pedagogical process on the formation of professional competence during the educational process in the following disciplines: general, preclinical, clinical, professional; management of educational practice on the basis of competence training. The priorities of orientation of the pedagogical process on the formation of professional competence of future nurses in the educational process of professional training of the medical college are revealed. Keywords: educational process, pedagogical process, future nurses, professional activity, professional competence.

$\Pi$ остановка проблеми. Основні положення Конституції України, Концепції розвитку охорони здоров'я населення України, Концепції державної політики інформатизації охорони здоров'я України, Закону України «Про вищу освіту», Програми розвитку медсестринства України знаходять своє відображення в освітніх стандартах, робочих програмах навчальних дисциплін, навчальних планах і спрямовують актуальність педагогічного процесу закладу вищої медичної освіти I-II рівня акредитащії на формування та становлення спеціаліста охорони здоров'я XXI століття, здатного надава- ти кваліфіковану медичну допомогу населенню України, які її потребують, проводячи при цьому свою фахову діяльність на демократичних та гуманістичних засадах, бути квалірікованим і конкурентноздатним фрахівцем на европейському та національному ринках пращі є надзвичайно важливим [6, с. 14$]$.

Сьогодні вітчизняна система охорони здоров'я все більше підтримуе програми розвитку та редормування охорони здоров'я, науково-практично обгрунтовуючи дієві шляхи підготовки майбутніх фрахівців охорони здоров'я. Пріоритетним напрямом реформування системи 
охорони здоров'я, середньої професійної освіти в Україні є підготовка кваліфрікованих майбутніх спеціалістів для надання належних профресійних медичних послуг населенню, відповідного фахового рівня і якості. Важливим питання нині є проблема формування професійної компетентності майбутніх медичних сестер в освітньому процесі фрахової підготовки медичного коледжу, що вимагає від майбутніх фрахівців особистісної свідомості, творчої активності, майстерного професіоналізму. Підготовка медичного працівника середньої ланки до майбутньої профресії в медичних освітніх закладах повинна бути всебічно Iрунтовною та цілісною, проводитися відповідно до державних освітніх стандартів, вимог суспільства, пріоритетних напрямів реформування вітчизняної системи охорони здоров'я.

Відповідно з переорієнтацією редормування системи охорони здоров'я на удосконалення первинної медичної допомоги із врахуванням принципів сучасної медицини актуальними $\epsilon$ нові вимоги щодо якості підготовки майбутніх медичних сестер, високої компетентності фрахівців із надання невідкладної медичної допомоги населенню та спрямованості педагогічного процесу на формування профресійної компетентності майбутніх медичних сестер.

Аналіз останніх досліджень і публікацій. Підготовці майбутніх медичних сестер до фрахової діяльності в медичних закладах освіти України приділено значну увагу щодо удосконалення медичної освіти I. Артемчуком, О. Біловол, I. Булах, Ю. Вороненко та ін.; в контексті концептуальних основ підготовки майбутніх фахівців у медичних коледжах - О. Горай, М. Демянчуком, Х. Мазепою, І. Мельничук, О. Маркович, І. Махновською та ін.; в контексті обгрунтування концептуальних основ профресійної підготовки та освітньої діяльності майбутніх фрахівців у медичних коледжах - А. Алексюком, Г. Васяновичем, Я. Цехмістер та ін.; приділенні концептуальних основ підготовки майбутніх медиків до професійної діяльності та шляхів педагогічного процесу на фрормування профресійної компетентності майбутніх медичних сестер до фрахової діяльності - Л. Вороновою, О. Гуменюк, Т. Закусиловою, О. Ковальчук, К. Куренковою, Ю. Лавриш, М. Лукащуком, О. Маркович, С. Мухіною, Т. Павлюк, М. Попіль, Л. Супрун, І. Тарновською, З. Шарлович, М. Шегединою та ін.

Виділення невирішених раніше частин загальної проблеми. Ірунтуючись на результатах проведеного теоретичного аналізу психолого-педагогічних джерел слід зазначити, що сучасний стан справ у державі все більше виявляе потребу вдосконалення системи підготовки майбутніх медичних сестер до фрахової діяльності. Серед важливих завдань системи підготовки середнього медичного персоналу до майбутньої профресійної діяльності є належне забезпечення кадрового потенціалу закладів охорони здоров'я, виховання та підготовленість майбутніх медичних сестер до профресійної діяльності з урахуванням відповідного рівня розвитку медичної науки, освіти та практики.

Актуальними невирішеними проблемами підготовки майбутніх медичних сестер до фрахової діяльності постають вимоги суспільства у май- бутніх медичних сестер з належним рівнем професійної підготовки до фрахової діяльності, потреби вдосконалення первинної медичної допомоги та відповідно до цього нові вимоги до якості підготовки здобувачів освіти, необхідність вдосконалення системи фрахової підготовки середнього медичного персоналу до майбутньої діяльності 3 належним рівнем профресійної компетентності та відповідальним станом особистісної готовності до професійної діяльності, широкою потребою належного кадрового забезпечення закладів охорони здоров'я.

Мета статті - теоретично обгрунтувати та з'ясувати пріоритети формування професійної компетентності майбутніх медичних сестер в освітньому процесі фрахової підготовки медичного коледжу.

Виклад основного матеріалу дослідження. Важливим завданням спрямованості педагогічного процесу на формування профресійної компетентності майбутніх медичних сестер є розвиток компетентних майбутніх медичних сестер, які можуть максимально втілювати свій потенціал у певній галузі профресійної діяльності із врахуванням змін, що відбуваються в соціальному, політичному, духовному та економічному житті нашої країни [2, с. 195].

Провідною метою підготовки майбутніх медичних сестер до фрахової діяльності в освітньому процесі медичного коледжу, є формування майбутнього професіонала нового зразка, в центрі фрахової діяльності якого є особистість з їі індивідуальними потребами, станом здоров'я та внутрішніми можливостями до адаптації; фрахівця, діяльність якого зосереджена на творчу, діалогічну та емпатійну взаємодію 3 пацієнтом, на активізацію потенційних можливостей, поліпшення і гармонізацію індивідуальних резервів; профресіонала, спроможного ефективно здійснювати якісних та фаховий догляд за хворими, надавати медичний догляд та встановлювати первинний медсестринський діагноз, виявляти проблеми пацієнта, належно виконувати призначення лікаря в амбулаторних і стаціонарних умовах [1, с. 103].

Водночас сфрера діяльності медичного працівника середньої ланки постійно розширюється згідно нових вимог до якості підготовки фрахівців охорони здоров'я і включає дедалі більше медичних процедур, які раніше не входили в їх компетенції. Сучасна клінічна практика потребує фахівців, які володіють новітніми методиками обстеження i догляду за хворими, та надання відповідних медичних послуг згідно існуючих европейських вимог [3, с. 26].

Основним, на думку науковців, має бути професійна спрямованість освітнього середовища медичного навчального закладу, що формує профресійну готовність випускників, яка проявляється в наявності професійно значущих ідеалів, інтересів, настанов, принципів, схильностей, здібностей, бажань і мотивів цілеспрямованої навчально-пізнавальної діяльності майбутніх dpaхівців із набуття знань і вмінь, необхідних для проведення обстеження, діагностування, лікування, відповідних медичних маніпуляцій, взаємодії з хворими й колегами, оцінювання впливу різноманітних чинників на стан хворих, розро- 
блення і впровадження заходів профрілактики захворювань і підтримки здорового способу життя людини [5, с. 18-23].

Майбутні медичні сестри нині мають володіти фрундаментальними знаннями та спеціальними вміннями щодо здійснення комплексного догляду за хворими; здатність аналітично мислити й творчо діяти, що пов'язані 3 їхніми фрункціональними обов'язками; спроможністю самовдосконалення та самонавчання [4, с. 8]. Це потребуе від медичних працівників готовності до постійного профресійного самовдосконалення. Таку готовність, на нашу думку, потрібно формувати в майбутніх фрахівцях ще під час їхнього навчання в медичному освітньому закладі, який, за словами Т. Комщук, є тим сощіумом, що спрямований на створення ефрективних умов для самовдосконалення, самореалізації та саморозвитку особистості [3, с. 26].

У медичних коледжах підготовка майбутніх медичних сестер до фрахової діяльності визначаеться спрямованістю на фрормування професійної кваліфрікованих знань, умінь і навичок та оволодіння майбутньою діяльністю. Вона виступає передумовою підготовленості до самореалізації як медичного персоналу, сприяе розвитку фрахових надбань впродовж всієї профресійної діяльності. Процес формування фрахових якостей медичного працівника середньої ланки визначається в значній мірі навчально-виховним середовищем освітнього закладу. Як стверджує Я. Цехмістер, на сучасному етапі вдосконалюеться й оновлюеться освітянський об'єм, відкриваються принципово нові потенційні можливості для відбору ефрективних засобів і технологій професійної підготовки медичних фрахівців, які сприяли б професійному становленню та гармонійному розвитку молодої людини [7, с. 65].

Формування професійної компетентності майбутніх медичних сестер в освітньому процесі фрахової підготовки медичного коледжу пов'язане 3 розвитком пізнавальної активності, особистісних якостей, творчого потенціалу, загальної культури, професійної майстерності з врахуванням:

- соціальної потреби професійної діяльності майбутніх медичних сестер;

- високих ціннісних якостей громадянина України та мотиващійних цінностей;

- усвідомлення майбутніми медичними сестрами необхідності професійної готовності до роботи у первинній ланці системи охорони здоров'я та в умовах запровадження страхової медицини;

- глибокої мотивації майбутніх медичних сестер до освітнього процесу на засадах компетентнісного підходу;

- наявності відповідних якостей для формування знань, умінь і навичок синтезувати та аналізувати інформацію, приймати фрахові рішення відповідно до сучасних стандартів надання медичної допомоги населенню з урахуванням сучасного рівня розвитку медичної науки і практики.

Структура профресійної підготовки майбутніх медичних сестер характеризується управлінням освітнім процесом медичного коледжу і шляхами підвищення ефрективності процесу підготовки майбутніх медичних сестер до фахової діяльності та розглядається як сукупність:
- соціального замовлення (якісна підготовка до фрахової діяльності для надання первинної лікувально-профілактичної долікарської допомоги населенню);

- педагогічної системи (ціль, мета, зміст, методи, форми, засоби і сукупність ряду чинників підсистем: маркетингова, матеріально-технічна, нормативноправова, фрінансово-економічна, управлінська;

- інформаційна, технічна, навчально-методична, які забезпечують освітній процес медичного коледжу);

- інфрормаційно-освітнього середовища медичного коледжу (педагогічно і технічно організована сфрера інфрормаційної взаємодії учасників освітнього процесу);

- управління освітнім процесом за напрямами підвищення ефективності процесу підготовки майбутніх медичних сестер: методи, засоби, фрорми, види робіт (методична, навчальна, виховна, наукова);

- зоорієнтованість педагогічного процесу на формування профресійної компетентності під час освітнього процесу за дисциплінами: загальноосвітні, доклінічні, клінічні, фрахові;

- управління навчальною практикою на засадах компетентнісного навчання (освітня діяльність під час виробничої практики, комплекс фрахових теоретико-практичних знань та завдань продесійного характеру для ефрективного фрормування вмінь і навичок роботи до майбутньої діяльності).

Важливими пріоритетами Формування продесійної компетентності майбутніх медичних сестер в освітньому процесі фрахової підготовки медичного коледжу є організація проведення освітнього процесу майбутніх медичних сестер на засадах компетентнісного підходу, яка характеризуеться комплексом заходів науково-методичного характеру (формування профресійної компетентності у майбутніх медичних сестер шляхом оволодіння прийомами, методами, засобами, формами, технологіями фрахової роботи) та навчально-освітнього характеру (пропедевтична робота, практична робота (освітня, лікувальна, профілактична, санітарно-фізіотерапевтична тощо), самостійна робота, індивідуальна робота, науково-дослідна робота) з врахуванням: соціальної потреби професійної діяльності майбутніх медичних сестер, високих щілісних якостей громадянина України та мотиваційних цінностей для досягнення суспільної й особистісної значущості, усвідомлення майбутніми медичними сестрами необхідності профресійної готовності до роботи у первинній ланщі системи охорони здоров'я та умов запровадження страхової медицини, глибокої мотивації майбутніх медичних сестер до профресійного навчання на засадах компетентнісного підходу, наявності відповідних якостей для формування знань, умінь і навичок синтезувати та аналізувати інформацію, приймати фрахові рішення відповідно до сучасних стандартів надання медичної допомоги населенню 3 урахуванням сучасного рівня розвитку медичної науки.

Висновки 3 даного дослідження i перспективи. Таким чином, стратегія держави в сорері медичної освіти має бути спрямована на формування профресійної компетентності майбутніх медичних сестер в освітньому процесі фрахової підготовки медичного коледжу 
3 урахуванням: потреби суспільства та сощіума в компетентнісних майбутніх медичних сестрах; модернізації медичної освіти на засадах компетентнісного підходу; професійної готовності майбутніх медичних сестрах до роботи у первинній ланщі системи охорони здоров'я; професійної підготовленості молодших спеціалістів до практичної діяльності; форомуванням їх профресіоналізму та адаптації до умов запровадження страхової медицини; високих суспільних цінностей для досягнення особистісної значущості, постійного профресійного самовдосконалення майбутніх медичних сестрах; глибокої мотиващії у майбутніх фрахівців до освітнього процесу та удосконалення особистісних фрахових компетентностей упродовж всієї професійної діяльності.

\section{Список літератури:}

1. Бабич М. Я. Формування професійних якостей майбутнього молодшого медичного спеціаліста як психологічна проблема. Актуальні питання теорії та практики психолого-педагогічної підготовки фбахівців за соціонолічнил профбілем : матеріали наук.-практ. конф. Хмельницький : ХНУ, 2011. С. 102-103.

2. Данюк М. I. Організація навчально-виховного процесу підготовки медичних сестер на засадах гуманної педагогіки. Сучасні інформаційні технологї та інноваційні методики навчання у підготовці фбахівців: методологія, теорія, досвід, проблели : зб. наук. пр. / ред. кол.: І. А. Зязюн та ін. Київ, Вінниця : ТОВ фірма «Планер», 2014. Вип. 39. С. 195-200.

3. Комщук Т. С. Етичні основи сестринської справи. Медсестринство. 2009. № 2. С. $25-27$.

4. Маркович О. В. Формування професійних умінь майбутніх медичних сестер хірургічного профрілю засобами алгоритмізації : автореф. дис. ... канд. пед. наук : 13.00.04. Київ, 2008. 20 с.

5. Неловкіна-Берналь О. А. Формування професійної спрямованості студентів медичних спеціальностей на початковому етапі навчання : автореф. дис. ... канд. пед. наук : 13.00.04. Луганськ, 2010. 23 с.

6. Програма розвитку медсестринства України (2005-2010 рр.). Медична освіта. 2006. № 1. С. 14-21.

7. Цехмістер Я. В. Теорія і практика допрофесійної підготовки учнів у ліцеях медичного профілю при вищих навчальних закладах : авторефр. дис. ... д-ра пед. наук : 13.00.04. Київ, 2002. 45 с.

\section{References:}

1. Babich M. Y. (2011) Formuvannia profesiinykh yakostei maibutnoho molodshoho medychnoho spetsialista yak psykholohichna problema [Formation of professional qualities of the future junior medical specialist as a psychological problem]. Proceedings of the Aktualni pytannia teorii ta praktyky psykholoho-pedahohichnoi pidhotovky fakhivtsiv za sotsionomichnym profilem (Ukraina, Khmelnytskyi, 2011), Khmelnytskyi: KhNU, pp. 102-103.

2. Daniuk M. I. (2014) Orhanizatsiia navchalno-vykhovnoho protsesu pidhotovky medychnykh sester na zasadakh humannoi pedahohiky [Organization of the educational process of training nurses on the basis of humane pedagogy]. Proceedings of the Suchasni informatsiini tekhnolohii ta innovatsiini metodyky navchannia $u$ pidhotovtsi fakhivtsiv: metodolohiia, teoriia, dosvid, problemy (Ukrainian, Kyiv, 2014) (eds. Ziaziun I. A.), Vinnytsia: TOV firma «Planer», vol. 39, pp. 195-200.

3. Komshchuk T. S. (2009) Etychni osnovy sestrynskoi spravy [Ethical foundations of nursing]. Medsestrynstvo, vol. 2, pp. 25-27.

4. Markovich O. V. (2008) Formuvannia profesiinykh umin maibutnikh medychnykh sester khirurhichnoho profiliu zasobamy alhorytmizatsii [Formation of professional skills of future nurses of surgical profile by means of algorithmization]. Extended abstract of Candidate's thesis (Pedag. Sciences: 13.00.04). Kyiv. (in Ukrainian)

5. Nelovkina-Bernal O. A. (2010) Formuvannia profesiinoi spriamovanosti studentiv medychnykh spetsialnostei na pochatkovomu etapi navchannia [Formation of professional orientation of medical students at the initial stage of study]. Extended abstract of Candidate's thesis (Pedag. Sciences: 13.00.04). Luhansk. (in Ukrainian)

6. Prohrama rozvytku medsestrynstva Ukrainy (2005-2010 rr.) (2006) Medychna osvita, vol. 1, pp. 14-21. (in Ukrainian)

7. Tsekhmister Y. V. (2002) Teoriia i praktyka doprofesiinoi pidhotovky uchniv u litseiakh medychnoho profiliu pry vyshchykh navchalnykh zakladakh [Theory and practice of preprofessional training of students in lyceums of medical profile at higher educational institutions]. Extended abstract of Candidate's thesis (Pedag. Sciences: 13.00.04). Kyiv. (in Ukrainian) 